\title{
Epigenetic regulation of thyroid hormone-induced adult intestinal stem cell development during anuran metamorphosis
}

\author{
Guihong Sun ${ }^{1}$, Liezhen Fu² and Yun-Bo Shi ${ }^{2 *}$
}

\begin{abstract}
Epigenetic modifications of histones are emerging as key factors in gene regulation by diverse transcription factors. Their roles during vertebrate development and pathogenesis are less clear. The causative effect of thyroid hormone (T3) on amphibian metamorphosis and the ability to manipulate this process for molecular and genetic studies have led to the demonstration that T3 receptor (TR) is necessary and sufficient for Xenopus metamorphosis, a process that resembles the postembryonic development (around birth) in mammals. Importantly, analyses during metamorphosis have provided some of the first in vivo evidence for the involvement of histone modifications in gene regulation by TR during vertebrate development. Furthermore, expression and functional studies suggest that various histone modifying epigenetic enzymes likely participate in multiple steps during the formation of adult intestinal stem cells during metamorphosis. The similarity between intestinal remodeling and the maturation of the mammalian intestine around birth when T3 levels are high suggests conserved roles for the epigenetic enzymes in mammalian adult intestinal stem cell development and/or proliferation.
\end{abstract}

Keywords: Thyroid hormone receptor, Stem cell, Metamorphosis, Xenopus laevis and tropicalis, Histone methylation, Histone acetylation, Intestine

\section{Introduction}

The adult mammalian intestine has long been served as a model system to study the property and function of adult organ-specific stem cells due to the constant selfrenewal of the intestinal epithelium throughout adult life $[1,2]$. In the adult mammalian intestine, the stem cells reside in the crypts. After stem cell division, the daughter cells migrate along the crypt-villus axis as they gradually differentiate into different types of epithelial cells. At the tip of the villus, the differentiated epithelial cells undergo apoptosis and are replaced by the newly arrived, differentiated epithelial cells, completing the self-renewing cycle once every 1-6 days [2-4]. Similar processes occur in the intestine in all vertebrates, including amphibians, with the epithelium being replaced once every 2 weeks in Xenopus laevis [5].

\footnotetext{
* Correspondence: Shi@helix.nih.gov

${ }^{2}$ Section on Molecular Morphogenesis, Program in Cellular Regulation and Metabolism (PCRM), Eunice Kennedy Shriver National Institute of Child Health and Human Development (NICHD), National Institutes of Health (NIH), 18 Library Dr, Bethesda, Maryland 20892, USA

Full list of author information is available at the end of the article
}

While many studies have been carried out on the mammalian intestinal stem cells in the adult, few have been on the formation of such stem cells during vertebrate development, largely due to the difficulty to manipulate uterus-enclosed mammalian embryos.

The frog intestine resembles the adult intestine in mammals. In the highly related species Xenopus laevis and tropicalis, the frog intestine contains numerous epithelial folds that resemble the crypt-villus structure in mammals [6,7]. The stem cells localized in the trough of the fold proliferate and the daughter cells differentiate into different epithelial cells as they migrate up toward the crest of the fold, where they undergo apoptosis. Interestingly, amphibians undergo biphasic development, first forming a free-living tadpole (Figure 1). After a finite period of premetamorphic growth, the tadpole metamorphoses into a frog. Accompanying this metamorphic transition, the animal intestine remodels extensively. The Xenopus tadpole intestine is a simple tubular structure made of mainly larval epithelial cells with little connective tissue or muscles (Figure 1). It has a single

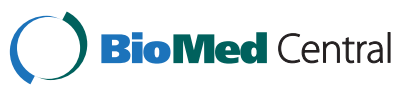

(c) 2014 Sun et al.; licensee BioMed Central Ltd. This is an Open Access article distributed under the terms of the Creative Commons Attribution License (http://creativecommons.org/licenses/by/4.0), which permits unrestricted use, distribution, and reproduction in any medium, provided the original work is properly credited. The Creative Commons Public Domain Dedication waiver (http://creativecommons.org/publicdomain/zero/1.0/) applies to the data made available in this article unless otherwise stated. 




epithelial fold, the typhlosole. During metamorphosis, the vast majority of the epithelial cells undergo apoptosis while some differentiated larval epithelial cells dedifferentiate into adult progenitor/stem cells, which subsequently proliferate and differentiate to form a multi-folded adult epithelium surrounded by extensive connective tissue and muscles [1,8-12]. As metamorphosis occurs totally independently of maternal influence, this offers a unique opportunity to study how adult organ-specific stem cells are formed during vertebrate development.

\section{Thyroid hormone (T3) and the formation of adult intestinal stem cells}

Both the maturation of the adult mammalian intestine and the remodeling of the intestine during frog metamorphosis occur when the plasma thyroid hormone (T3) concentrations are high, a period referred to as postembryonic development [13]. Importantly, T3 plays a causative and organ-autonomous role during amphibian metamorphosis $[14,15]$. T3-treatment of premetamorphic tadpoles or tadpole organ cultures induces precocious metamorphosis while blocking the synthesis of endogenous T3 inhibits natural metamorphosis. This has enabled cellular, molecular, and genetic analyses on the formation of the adult intestinal stem cells during intestinal metamorphosis [1,16-18]. By using recombinant organ-cultures made of wild type and transgenic animals expressing GPF, we have shown that adult epithelial stem cells formed upon T3 treatment of the organ cultures of premetamorphic intestine originate from the larval epithelium [8].

Extensive studies indicate that T3 controls Xenopus metamorphosis by regulating gene transcription through nuclear T3 receptors (TRs) [19-31]. To investigate the role of TR in adult intestinal stem cell development, we have made use of recombinant organ-cultures consisting of tissues from wild type and transgenic animals expressing a dominant positive TR (dpTR) under the control of a heat shock-inducible promoter $[10,22]$. We have shown that inducible expression of the dpTR in all tissues of the intestine in the absence of T3 is sufficient to induce intestinal metamorphosis, including larval epithelial cell death and adult stem cell formation, suggesting that TR is both necessary and sufficient for the inductive effects of T3 on stem cell formation [10]. Furthermore, expression of dPTR in the larval epithelium alone is able to induce the dedifferentiation of larval epithelial cells to upregulate sonic hedgehog gene, which is highly expressed in the proliferating adult epithelial progenitor/stem cells. Interestingly, such cells fail to upregulate the expression of two well-known markers of the adult mammalian intestinal stem cells and the formation of the stem cells expressing such markers also requires the expression of dpTR in the rest of the intestinal organ culture, i.e., the nonepithelium [10], consistent with earlier studies showing 
an requirement for cell-cell interaction during the formation of the adult intestine [28,32]. These findings suggest that TR-mediated gene regulation in both the epithelium and the non-epithelium are required for stem cell development, with the T3-induced gene expression changes in the non-epithelium likely contribute to the formation of the stem cell niche for the developing adult stem cells. Many such tissue-specific T3-regulated genes have been identified and the analyses of the spatiotemporal expression profiles of some of the epithelial genes indeed support their involvement in adult stem cell formation/proliferation [33-37].

\section{Mechanism of gene regulation by TR during Xenopus development}

TR can both activate and repress gene transcription. For T3-induced genes, TR most likely functions as heterodimers formed with 9-cis retinoic acid receptors (RXRs), another number of the nuclear hormone receptor superfamily [38-42]. TR/RXR heterodimers bind to T3-response elements (TREs) in target genes constitutively and regulates their expression in a T3-dependent manner [38-41,43-45]. In the absence of T3, TR binds to corepressors such as the two highly related proteins NCoR (nuclear corepressor) and SMRT (silencing mediator of retinoid and thyroid hormone receptors), which form large histone deacetylase (HDAC)-containing complexes [46-62]. In the presence of T3, TR recruits diverse coactivator complexes, such as ATP-dependent chromatin remodelers and histone acetyltransferase/methyltransferase-containing complexes [39,51,63-84]. Thus, TR likely regulates gene transcription in part through chromatin remodeling and histone modifications.

Molecular studies during frog development were the first to provide strong evidence for the involvement of epigenetic changes in gene regulation by TR during vertebrate development. First, chromatin immunoprecipitation (ChIP) assay has shown that TR and RXR bind to T3inducible genes constitutively in pre- and metamorphosing Xenopus laevis and tropicalis tadpoles $[85,86]$. Second, gene regulation by $\mathrm{T} 3$ during $\mathrm{T} 3$-induced as well as natural metamorphosis is accompanied by increases in the histone acetylation levels at the target genes as well as the release of corepressor complexes and the recruitment of coactivator complexes [62,76,81-85,87-89]. More importantly, treatment premetamorphic tadpoles with the HDAC inhibitor tricostatin A (TSA) inhibits HDAC activity in tadpole tissues and derepresses T3-response genes in the absence of T3 (Figures 2 and 3) [90,91]. Finally, ChIP analyses of total histones and different histone acetylation and methylation marks have shown that T3 treatment leads to the removal of core histones at the T3 target genes, and a

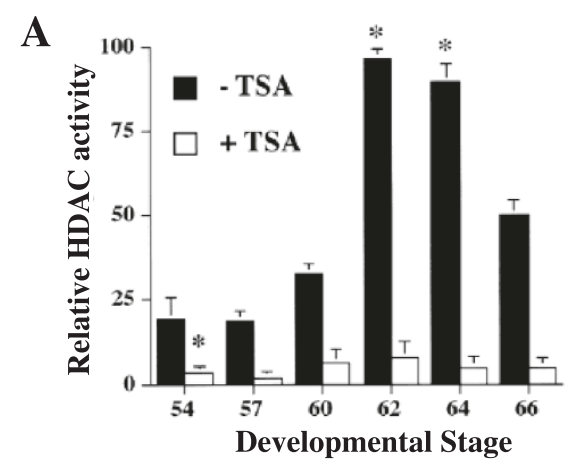

C

B

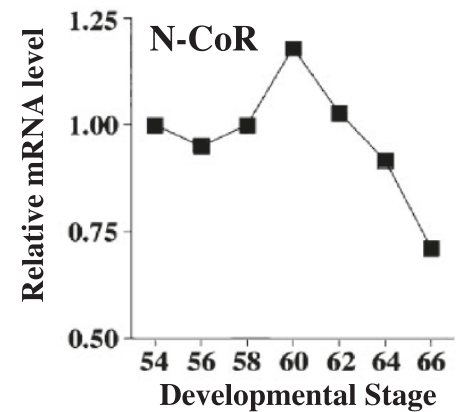

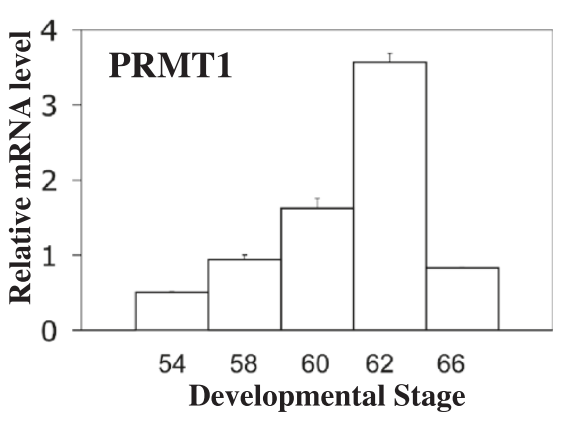

D

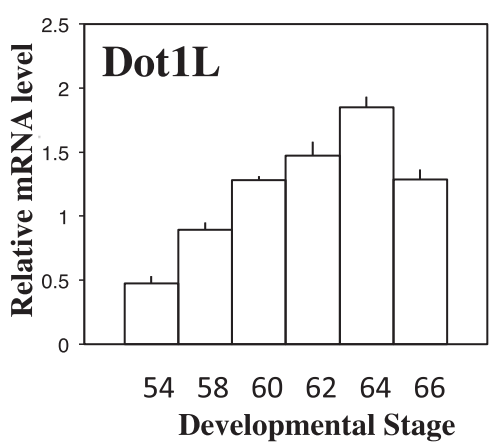

Figure 2 Upregulation of genes involved in epigenetic modifications during intestinal stem cell development. (A) HDAC activity. Intestinal protein extracts were prepared from Xenopus laevis tadpoles at different stages and assayed for HDAC activity in the presence or absence of $10 \mathrm{nM}$ TSA, an HDAC inhibitor. Means +/- SEMs are given. Statistical significance as compared with the stage 54 animals is expressed as *: P $<0.01$. Note that the HDAC-specific drug TSA inhibited all activities. See [91] for details. (B)-(D). The relative mRNA levels of N-CoR (B), PRMT1 (C), and Dot1L (D). The mRNA levels were determined by using total RNA from intestine at different stages during Xenopus laevis development. See $[76,87,98]$ for details. 
reduction in the levels of repression histone modification marks and an increase in the levels of activation histone modification marks in the remaining nucleosomes $[31,88,89,92]$. This is consistent with earlier studies in the reconstituted frog oocyte transcription system, where the ordered nucleosomal organization of the minichromosome containing a T3-responsive promoter assembled in the Xenopus laevis oocyte, was found to be disrupted by TR/RXR in the presence but not in the absence of T3 $[43,44,93,94]$. The exact mechanisms for the chromatin remodeling are yet to be determined. It is likely that the release of the HDAC-containing $\mathrm{N}-\mathrm{CoR} / \mathrm{SMRT}$ complexes contributes to the increased acetylation at the target genes. Likewise, the recruitment of the coactivator complexes, such as the chromatin remodeling complexes containing Brg1 and BAF57 and histone modification complexes containing acetyltransferases SRC and p300 and methyltransferases PRMT1 and CARM1, would help to remodel the chromatin and alter histone modifications at the promoter regions $[21,31,62-64,76,77,81-85,87-89]$.

\section{Regulation of genes encoding epigenetic enzymes during intestinal stem cell development}

The changes in the levels of various histone modifications upon gene activation by $\mathrm{T} 3$ argue for a role of epigenetic genes during adult intestinal stem cell development. Interestingly, when HDAC activity and HDAC1 (Rpd3) expression were analyzed in the metamorphosing intestine, both were found to be low in premetamorphic tadpoles (Figure 2A) [91] and strongly upregulated at the climax of metamorphosis (stages 60-62) when stem cells are forming and proliferating [91]. Similar observation was made for the expression of the TR-binding corepressor N-CoR (Figure 2B) [87], which forms complexes with HDACs $[56,61,95]$. Thus, it is likely that in addition to their roles in facilitating repression by unliganded TR (see above), the HDAC-containing corepressor complexes may also play a role during metamorphosis when $\mathrm{T} 3$ is present (see below). Among the histone acetyltransferases analyzed, SRC3 were found to be upregulated during intestinal metamorphosis while SRC1 and p300 changed little during metamorphosis in the intestine [96].

In addition, several histone methyltransferases are also expressed in the metamorphosing intestine. The histone H3R17 methyltransferase CAMR1 is expressed constitutively during metamorphosis [77] while the histone H4R3 methyltransferase PRMT1 is upregulated by T3 during both natural and T3-induced intestinal metamorphosis (Figure 2C) [76]. More recent promoter analyses have suggested that PRMT1 is indirectly induced by T3, in part through the activation of c-Myc gene [97], a transcription factor that is known to be important for stem cells and cell proliferation in general.
Another histone methyltransferase, Dot1L (Dot1-like), the only known histone H3K79 methyltransferase, has been shown to be upregulated in the intestine during metamorphosis (Figure 2D) and its induction is directly at the transcription level through the binding of TR to a TRE in its promoter [98]. Thus, multiple histone methyltransferases appear to be involved in the adult intestinal stem cell development.

\section{Distinct roles of epigenetic enzymes at multiple steps of intestinal stem cell development}

As indicated above, unliganded TR recruits HDACcontaining corepressor complexes to T3-target genes in different organs of premetamorphic tadpoles, including the intestine, while liganded TR recruits coactivator complexes containing histone acetyltransferases and methyltransferases. These enable TR to play a dual function role during frog development, repressing T3inducible genes to prevent premature metamorphosis in the absence of $\mathrm{T} 3$ while activating these genes to induce metamorphosis when T3 is present [24]. The involvement of HDAC(s) in gene repression by unliganded TR has been substantiated by the ChIP analyses on histone acetylation levels at the T3 target genes $[90,91]$. Furthermore, overexpression of a dominant negative corepressor $\mathrm{N}$-CoR that disrupts the formation of an active HDAC-containing corepressor complex at $\mathrm{T} 3$ target genes results in precocious initiation of metamorphosis and the upregulation of T3 target genes [99]. Thus, HDAC activity plays an important role to repress TR target genes in the premetamorphic tadpole intestine to prevent precocious formation of adult stem cells. Interestingly, the expression of N-CoR and HDAC1 as well as HDAC activity is strongly upregulated during intestinal metamorphosis (Figure 2). Thus, HDAC activity is likely also important for one or more steps downstream of gene activation by liganded TR. This dual role of HDACs in intestinal development has been supported by molecular studies using the HDAC inhibitor TSA. TSA treatment of premetamorphic

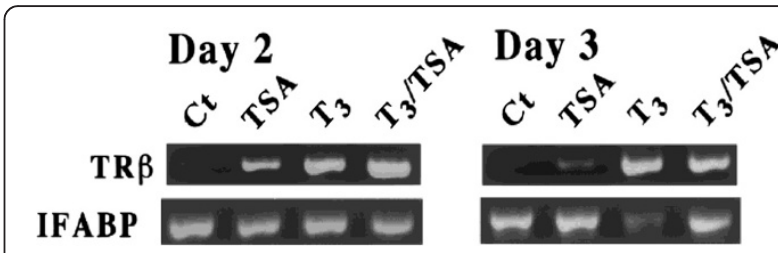

Figure 3 TSA induces direct TR target genes but blocks the regulation of late $T_{3}$-response genes in premetamorphic tadpole intestine. Stage 55 tadpoles were treated with $\mathrm{T}_{3}(5 \mathrm{nM})$ and/or TSA $(100 \mathrm{nM})$ for the indicated number of days. Total RNA was extracted from isolated intestine and assayed by PCR for the mRNA levels of indicated genes. IFAPB: intestinal fatty acid binding protein. See [91] for details. 
tadpoles for 2-3 days in the absence of T3 leads to upregulation of T3-target genes such as TR $\beta$, while in the presence of T3, little effect is observed (Figure 3) [91]. This agrees with the mechanism that unliganded TR represses TR target genes by recruiting HDAC-containing complexes and inhibiting HDACs will thus depress the genes. In the presence of $\mathrm{T} 3$, the HDAC-complexes are released from the T3 target promoters and thus inhibiting HDAC will have no effect. Interestingly, TSA surprisingly inhibits T3-induced metamorphosis and the regulation of downstream T3 response genes [91]. For example, in the animal intestine, the formation and/or proliferation of the adult epithelial stem cells is inhibited by TSA treatment [91]. Likewise, the downregulation of intestinal fatty acid binding protein (IFABP) gene after prolonged T3-treatment, which accompanies larval epithelial cell death and adult stem cell development, is also blocked by TSA (Figure 3). Thus, histone deacetylation appears to also function at a step(s) down-stream of gene regulation induced by liganded TR to affect the regulation of genes involved in the subsequent steps important for adult intestinal stem cell formation.

Among the histone methyltransferases known to be expressed during intestinal metamorphosis, both CARM1 and PRMT1 are TR-coactivators and likely act at least in part to enhance the transcriptional regulation by liganded TR to promote adult stem cell development. Indeed, transgenic overexpression of wild type PRMT1 leads to an increased number of intestinal stem cells during metamorphosis while antisense morpholino-mediated PRMT1 knockdown reduces the number of such stem cells [11]. Thus, PRMT1 is important for the formation and/or proliferation of adult intestinal progenitor/stem cells during metamorphosis. Mechanistically, we have shown that overexpression of PRMT1 indeed enhances the activation of T3-target genes in the presence of T3 in tadpoles. On the other hand, it is very likely that PRMT1 can also function to epigenetically influence the expression of genes regulated by some other transcription factors during stem cell development.

The third methyltransferase, Dot $1 \mathrm{~L}$, is the only known histone methyltransferase capable of methylating histone H3K79 [100]. Interestingly, ChIP analyses have revealed that the levels of H3K79 methylation at T3 target promoters are strongly increased during either natural or T3-induced metamorphosis in the intestine [89]. These findings suggest that T3 activates the Dot1L gene, and Dot1L in turn feeds back positively as a TR coactivator during metamorphosis by methylating H3K79 at T3 target genes to enhance gene activation and intestinal stem cell development. On the other hand, like PRMT1, Dot1L may also influence the activity of other transcription factors during intestinal metamorphosis.

\section{Conclusion}

Ever increasing evidence supports the view that histone modifications are key epigenetic marks that can influence gene expression during development and pathogenesis. Each eukaryotic nucleosome contains four core histones ( $\mathrm{H} 2 \mathrm{~A}, \mathrm{H} 2 \mathrm{~B}, \mathrm{H} 3$, and $\mathrm{H} 4)$. These histones, particularly their $\mathrm{N}$-terminal tails, are subject to various posttranslational modifications, including acetylation and methylation, etc. [101]. A number of histone activation and repression marks have been identified based on the correlations of histone modifications at individual genes with the levels of the corresponding mRNAs as determined by genome wide ChIP and gene expression analyses in cell cultures [102-110]. The total dependence of amphibian metamorphosis on T3 and TR and the ability to easily manipulate this process for molecular and genetic studies [20,23,31,111] have enabled the analyses of some of these modifications in vivo. These studies have shown that most histone modification marks, although not all, are similarly correlated with gene regulation by TR during Xenopus metamorphosis and adult intestinal stem cell development $[88,89,92]$, suggesting that TR utilizes such epigenetic modifications to control gene expression during vertebrate development. Importantly, the distinct spatiotemporal expression profiles of various epigenetic enzymes during intestinal remodeling implicates complex roles of epigenetic enzymes during adult intestinal stem cell development. In particularly, HDAC activity appears to be required not only by unliganded TR to prevent precocious intestinal metamorphosis in premetamorphic tadpoles but also at one or more steps downstream of gene activation by liganded TR for adult intestinal stem cell development. Similarly, the histone methyltransferases CARM1, PRMT1, and Dot1L are likely involved both as coactivators for TR and in the downstream events leading to the formation of adult intestinal stem cells. Interestingly, a number of studies have also revealed the importance of epigenetic modifications for other adult organ-specific stem cells [112-114]. Clearly, functional studies by using overexpression and knockdown approaches in vivo [115-119] are needed to determine the exact roles of these epigenetic enzymes for Xenopus intestinal stem cell development. Furthermore, the similarity between amphibian metamorphosis and postembryonic development (the period around birth when T3 levels are high) $[13,15]$, and in particular between intestinal metamorphosis and mammalian intestinal maturation $[17,120]$, suggests conserved roles for the epigenetic enzymes in the formation and/or proliferation of adult vertebrate intestinal stem cells.

Competing interests

The authors declare that they have no competing interests. 


\section{Authors' contributions}

All authors participated in the writing of the review. All authors read and approved the final manuscript.

\section{Acknowledgement}

This work was supported by the intramural Research Program of $\mathrm{NICHD}, \mathrm{NIH}$ and National Natural Science Foundation of China (Grant No. 31370187 and 30870113)

\section{Author details}

${ }^{1}$ School of Basic Medical Sciences, Wuhan University, Wuhan 430072, P.R. China. ${ }^{2}$ Section on Molecular Morphogenesis, Program in Cellular Regulation and Metabolism (PCRM), Eunice Kennedy Shriver National Institute of Child Health and Human Development (NICHD), National Institutes of Health (NIH), 18 Library Dr, Bethesda, Maryland 20892, USA.

Received: 29 September 2014 Accepted: 18 November 2014 Published: 28 November 2014

\section{References}

1. Shi YB, Hasebe T, Fu L, Fujimoto K, Ishizuya-Oka A: The development of the adult intestinal stem cells: Insights from studies on thyroid hormonedependent amphibian metamorphosis. Cell Biosci 2011, 1(1):30.

2. van der Flier LG, Clevers H: Stem Cells, Self-Renewal, and Differentiation in the Intestinal Epithelium. Annu Rev Physiol 2009, 71:241-260.

3. MacDonald WC, Trier JS, Everett NB: Cell proliferation and migration in the stomach, duodenum, and rectum of man: Radioautographic studies. Gastroenterology 1964, 46:405-417.

4. Toner PG, Carr KE, Wyburn GM: The Digestive System: An Ultrastructural Atlas and Review. London: Butterworth; 1971.

5. McAvoy JW, Dixon KE: Cell proliferation and renewal in the small intestinal epithelium of metamorphosing and adult Xenopus laevis. J Exp Zool 1977, 202:129-138.

6. Shi Y-B, Ishizuya-Oka A: Biphasic intestinal development in amphibians: Embryogensis and remodeling during metamorphosis. Current Topics in Develop Biol 1996, 32:205-235.

7. Sterling J, Fu L, Matsuura K, Shi Y-B: Cytological and morphological analyses reveal distinct features of intestinal development during Xenopus tropicalis metamorphosis. PLoS One 2012, 7:e47407. 47401-47410.

8. Ishizuya-Oka A, Hasebe T, Buchholz DR, Kajita M, Fu L, Shi YB: Origin of the adult intestinal stem cells induced by thyroid hormone in Xenopus laevis. Faseb J 2009, 23:2568-2575.

9. Schreiber AM, Cai L, Brown DD: Remodeling of the intestine during metamorphosis of Xenopus laevis. Proc Natl Acad Sci U S A 2005, 102(10):3720-3725.

10. Hasebe T, Buchholz DR, Shi YB, Ishizuya-Oka A: Epithelial-connective tissue interactions induced by thyroid hormone receptor are essential for adult stem cell development in the Xenopus laevis intestine. Stem Cells 2011, 29(1):154-161

11. Matsuda H, Shi YB: An essential and evolutionarily conserved role of protein arginine methyltransferase 1 for adult intestinal stem cells during postembryonic development. Stem Cells 2010, 28(11):2073-2083.

12. Sun G, Hasebe T, Fujimoto K, Lu R, Fu L, Matsuda H, Kajita M, Ishizuya-Oka A, Shi YB: Spatio-temporal expression profile of stem cell-associated gene LGR5 in the intestine during thyroid hormone-dependent metamorphosis in Xenopus laevis. PLoS One 2010, 5(10):e13605.

13. Tata JR: Gene expression during metamorphosis: an ideal model for post-embryonic development. Bioessays 1993, 15(4):239-248.

14. Gilbert LI, Tata JR, Atkinson BG: Metamorphosis: Post-embryonic reprogramming of gene expression in amphibian and insect cells. New York: Academic Press; 1996.

15. Shi Y-B: Amphibian Metamorphosis: From morphology to molecular biology. New York: John Wiley \& Sons, Inc; 1999.

16. Ishizuya-Oka A, Hasebe T: Establishment of intestinal stem cell niche during amphibian metamorphosis. Curr Top Dev Biol 2013, 103:305-327.

17. Ishizuya-Oka A, Shi YB: Evolutionary insights into postembryonic development of adult intestinal stem cells. Cell Biosci 2011, 1(1):37.

18. Hasebe T, Fu L, Miller TC, Zhang Y, Shi YB, Ishizuya-Oka A: Thyroid hormone-induced cell-cell interactions are required for the development of adult intestinal stem cells. Cell Biosci 2013, 3(1):18.
19. Schreiber AM, Das B, Huang H, Marsh-Armstrong N, Brown DD: Diverse developmental programs of Xenopus laevis metamorphosis are inhibited by a dominant negative thyroid hormone receptor. PNAS 2001, 98:10739-10744.

20. Brown DD, Cai L: Amphibian metamorphosis. Dev Biol 2007, 306(1):20-33.

21. Buchholz DR, Hsia VS-C, Fu L, Shi Y-B: A dominant negative thyroid hormone receptor blocks amphibian metamorphosis by retaining corepressors at target genes. Mol Cell Biol 2003, 23:6750-6758.

22. Buchholz DR, Tomita A, Fu L, Paul BD, Shi Y-B: Transgenic analysis reveals that thyroid hormone receptor is sufficient to mediate the thyroid hormone signal in frog metamorphosis. Mol Cell Biol 2004, 24:9026-9037.

23. Buchholz DR, Paul BD, Fu L, Shi YB: Molecular and developmental analyses of thyroid hormone receptor function in Xenopus laevis, the African clawed frog. Gen Comp Endocrinol 2006, 145(1):1-19.

24. Shi Y-B: Dual functions of thyroid hormone receptors in vertebrate development: the roles of histone-modifying cofactor complexes. Thyroid 2009, 19:987-999.

25. Nakajima K, Yaoita Y: Dual mechanisms governing muscle cell death in tadpole tail during amphibian metamorphosis. Dev Dyn 2003, 227:246-255.

26. Denver RJ, Hu F, Scanlan TS, Furlow JD: Thyroid hormone receptor subtype specificity for hormone-dependent neurogenesis in Xenopus laevis. Dev Biol 2009, 326(1):155-168.

27. Bagamasbad P, Howdeshell KL, Sachs LM, Demeneix BA, Denver RJ: A role for basic transcription element-binding protein 1 (BTEB1) in the autoinduction of thyroid hormone receptor beta. J Biol Chem 2008, 283:2275-2285.

28. Schreiber AM, Mukhi S, Brown DD: Cell-cell interactions during remodeling of the intestine at metamorphosis in Xenopus laevis. Dev Biol 2009, 331(1):89-98.

29. Sachs LM, Damjanovski S, Jones PL, Li Q, Amano T, Ueda S, Shi YB, Ishizuya-Oka $A$ : Dual functions of thyroid hormone receptors during Xenopus development. Comp Biochem Physiol B Biochem Mol Biol 2000, 126(2):199-211.

30. Shi Y-B: Molecular biology of amphibian metamorphosis: A new approach to an old problem. Trends Endocrinol Metab 1994, 5:14-20.

31. Shi YB, Matsuura K, Fujimoto K, Wen L, Fu L: Thyroid hormone receptor actions on transcription in amphibia: The roles of histone modification and chromatin disruption. Cell Biosci 2012, 2(1):42.

32. Ishizuya-Oka A, Shimozawa A: Connective tissue is involved in adult epithelial development of the small intestine during anuran metamorphosis in vitro. Roux's Arch Dev Biol 1992, 201:322-329.

33. Luu N, Wen L, Fu L, Fujimoto K, Shi YB, Sun G: Differential regulation of two histidine ammonia-lyase genes during Xenopus development implicates distinct functions during thyroid hormone-induced formation of adult stem cells. Cell Biosci 2013, 3(1):43.

34. Sun G, Heimeier RA, Fu L, Hasebe T, Das B, Ishizuya-Oka A, Shi Y-B: Expression Profiling of Intestinal Tissues Implicates Tissue-Specific Genes and Pathways Essential for Thyroid Hormone-Induced Adult Stem Cell Development. Endocrinology 2013, 154(11):4396-4407.

35. Miller TC, Sun G, Hasebe T, Fu L, Heimeier RA, Das B, Ishizuya-Oka A, Shi YB: Tissue-specific upregulation of MDS/EVI gene transcripts in the intestine by thyroid hormone during Xenopus metamorphosis. PLoS One 2013, 8(1):e55585.

36. Sun G, Fu L, Wen L, Shi Y-B: Activation of Sox3 gene by thyroid hormone in the developing adult intestinal stem cell during Xenopus metamorphosis. Endocrinology 2014, in press.

37. Ishizuya-Oka A, Ueda S, Inokuchi T, Amano T, Damjanovski S, Stolow M, Shi Y-B: Thyroid hormone-induced expression of Sonic hedgehog correlates with adult epithelial development during remodeling of the Xenopus stomach and intestine. Differentiation 2001, 69:27-37.

38. Lazar MA: Thyroid hormone receptors: multiple forms, multiple possibilities. Endocr Rev 1993, 14(2):184-193.

39. Yen PM: Physiological and molecular basis of thyroid hormone action Physiol Rev 2001, 81(3):1097-1142.

40. Mangelsdorf DJ, Thummel C, Beato M, Herrlich P, Schutz G, Umesono K, Blumberg B, Kastner $\mathrm{P}$, Mark M, Chambon P: The nuclear receptor superfamily: the second decade. Cell 1995, 83(6):835-839.

41. Tsai MJ, O'Malley BW: Molecular mechanisms of action of steroid/thyroid receptor superfamily members. Ann Rev Biochem 1994, 63:451-486.

42. Laudet V, Gronemeyer H: The nuclear receptor FactsBook. San Diego: Academic Press; 2002 
43. Wong J, Shi YB, Wolffe AP: A role for nucleosome assembly in both silencing and activation of the Xenopus TR beta A gene by the thyroid hormone receptor. Genes Dev 1995, 9(21):2696-2711.

44. Wong J, Shi Y-B, Wolffe AP: Determinants of chromatin disruption and transcriptional regulation instigated by the thyroid hormone receptor: hormone-regulated chromatin disruption is not sufficient for transcriptinal activation. EMBO J 1997, 16:3158-3171.

45. Wong J, Patterton D, Imhof D, Guschin D, Shi Y-B, Wolffe AP: Distinct requirements for chromatin assembly in transcriptional repression by thyroid hormone receptor and histone deacetylase. EMBO J 1998, 17:520-534.

46. Horlein AJ, Naar AM, Heinzel T, Torchia J, Gloss B, Kurokawa R, Ryan A, Kamei Y, Soderstrom M, Glass CK, Rosenfeld MG: Ligand-independent repression by the thyroid hormone receptor mediated by a nuclear receptor co-repressor. Nature 1995, 377(6548):397-404

47. Chen JD, Evans RM: A transcriptional co-repressor that interacts with nuclear hormone receptors. Nature 1995, 377:454-457.

48. Burke $\amalg$, Baniahmad A: Co-repressors 2000. FASEB J 2000, 14(13):1876-1888.

49. Jones PL, Shi Y-B: N-CoR-HDAC corepressor complexes: Roles in transcriptional regulation by nuclear hormone receptors. In Current Topics in Microbiology and Immunology: Protein Complexes that Modify Chromatin, Volume 274. Edited by Workman JL. Berlin: Springer-Verlag; 2003:237-268.

50. Glass CK, Rosenfeld MG: The coregulator exchange in transcriptional functions of nuclear receptors. Genes Dev 2000, 14(2):121-141.

51. Zhang J, Lazar MA: The mechanism of action of thyroid hormones. Annu Rev Physiol 2000, 62:439-466.

52. Yoon H-G, Chan DW, Huang ZQ, Li J, Fondell JD, Qin J, Wong J: Purification and functional characterization of the human N-CoR complex: the roles of HDAC3, TBL1 and TBLR1. Embo J 2003, 22:1336-1346.

53. Zhang J, Kalkum M, Chait BT, Roeder RG: The N-CoR-HDAC3 nuclear receptor corepressor complex inhibits the JNK pathway through the integral subunit GPS2. Mol Cell 2002, 9:611-623.

54. Ishizuka T, Lazar MA: The N-CoR/histone deacetylase 3 complex is required for repression by thyroid hormone receptor. Mol Cell Biol 2003, 23:5122-5131.

55. Guenther MG, Lane WS, Fischle W, Verdin E, Lazar MA, Shiekhattar R: A core SMRT corepressor complex containing HDAC3 and TBL1, a WD40-repeat protein linked to deafness. Genes \& Devel 2000, 14:1048-1057.

56. Li J, Wang J, Wang J, Nawaz Z, Liu JM, Qin J, Wong J: Both corepressor proteins SMRT and $\mathrm{N}$-CoR exist in large protein complexes containing HDAC3. Embo J 2000, 19:4342-4350.

57. Perissi $V$, Jepsen $K$, Glass CK, Rosenfeld MG: Deconstructing repression: evolving models of co-repressor action. Nat Rev Genet 2010, 11:109-123.

58. Stewart D, Tomita A, Shi YB, Wong J: Chromatin immunoprecipitation for studying transcriptional regulation in Xenopus oocytes and tadpoles. Methods Mol Biol 2006, 322:165-181.

59. Stewart MD, Li J, Wong J: Relationship between histone H3 lysine 9 methylation, transcription repression, and heterochromatin protein 1 recruitment. Mol Cell Biol 2005, 25(7):2525-2538.

60. Li J, Lin Q, Yoon HG, Huang ZQ, Strahl BD, Allis CD, Wong J: Involvement of histone methylation and phosphorylation in regulation of transcription by thyroid hormone receptor. Mol Cell Biol 2002, 22:5688-5697.

61. Jones PL, Sachs LM, Rouse N, Wade PA, Shi YB: Multiple N-CoR complexes contain distinct histone deacetylases. J Biol Chem 2001, 276(12):8807-8811

62. Tomita A, Buchholz DR, Shi Y-B: Recruitment of N-CoR/SMRT-TBLR1 corepressor complex by unliganded thyroid hormone receptor for gene repression during frog development. Mol Cell Biol 2004, 24:3337-3346.

63. Heimeier RA, Hsia VS-C, Shi Y-B: Participation of BAF57 and BRG1-Containing Chromatin Remodeling Complexes in Thyroid Hormone-Dependent Gene Activation during Vertebrate Development. Mol Endocrinol 2008 22:1065-1077.

64. Huang Z-Q, Li J, Sachs LM, Cole PA, Wong J: A role for cofactor-cofactor and cofactor-histone interactions in targeting p300, SWI/SNF and Mediator for transcription. EMBO J 2003, 22:2146-2155.

65. McKenna NJ, O'Malley BW: Nuclear receptors, coregulators, ligands, and selective receptor modulators: making sense of the patchwork quilt. Ann N Y Acad Sci 2001, 949:3-5.

66. Rachez C, Freedman LP: Mediator complexes and transcription. Curr Opin Cell Biol 2001, 13(3):274-280
67. Ito M, Roeder RG: The TRAP/SMCC/Mediator complex and thyroid hormone receptor function. Trends Endocrinol Metab 2001, 12(3):127-134.

68. Sheppard HM, Harries JC, Hussain S, Bevan C, Heery DM: Analysis of the steroid receptor coactivator 1 (SRC1)-CREB binding protein interaction interface and its importance for the function of SRC1. Mol Cell Biol 2001, 21:39-50.

69. Chen H, Lin RJ, Schiltz RL, Chakravarti D, Nash A, Nagy L, Privalsky ML, Nakatani Y, Evans RM: Nuclear receptor coactivator ACTR is a novel histone acetyltransferase and forms a multimeric activation complex with P/CAF and CBP/p300. Cell 1997, 90:569-580.

70. Demarest SJ, Martinez-Yamout M, Chung J, Chen H, Xu W, Dyson HJ, Evans $\mathrm{RM}$, Wright PE: Mutual synergistic folding in recruitment of CBP/p300 by p160 nuclear receptor coactivators. Nature 2002, 415:549-553.

71. Onate SA, Tsai SY, Tsai MJ, O'Malley BW: Sequence and characterization of a coactivator for the steroid hormone receptor superfamily. Science 1995 , 270(5240):1354-1357

72. Li J, O'Malley BW, Wong J: p300 requires its histone acetyltransferase activity and SRC-1 interaction domain to facilitate thyroid hormone receptor activation in chromatin. Mol And Cell Biol 2000, 20(6):2031-2042.

73. Torchia J, Rose DW, Inostroza J, Kamei Y, Westin S, Glass CK, Rosenfeld MG: The transcriptional co-activator $\mathrm{p} / \mathrm{CIP}$ binds CBP and mediates nuclearreceptor function. Nature 1997, 387:677-684.

74. Chen D, Ma H, Hong H, Koh SS, Huang SM, Schurter BT, Aswad DW, Stallcup MR: Regulation of transcription by a protein methyltransferase. Science 1999, 284:2174-2177

75. Koh SS, Chen DG, Lee YH, Stallcup MR: Synergistic enhancement of nuclear receptor function by 160 coactivators and two coactivators with protein methyltransferase activities. J Biol Chem 2001, 276:1089-1098.

76. Matsuda H, Paul BD, Choi CY, Hasebe T, Shi Y-B: Novel functions of protein arginine methyltransferase 1 in thyroid hormone receptor-mediated transcription and in the regulation of metamorphic rate in Xenopus laevis. Mol Cell Biol 2009, 29:745-757.

77. Matsuda H, Paul BD, Choi CY, Shi Y-B: Contrasting effects of two alternative splicing forms of coactivator-associated arginine methyltransferase 1 on thyroid hormone receptor-mediated transcription in Xenopus laevis. Mol Endocrinology 2007, 21(5):1082-1094.

78. O'Malley BW, Malovannaya A, Qin J: Minireview: nuclear receptor and coregulator proteomics-2012 and beyond. Mol Endocrinol 2012, 26(10):1646-1650.

79. Bulynko YA, O'Malley BW: Nuclear receptor coactivators: structural and functional biochemistry. Biochemistry 2011, 50(3):313-328.

80. McKenna NJ, Cooney AJ, DeMayo FJ, Downes M, Glass CK, Lanz RB, Lazar MA, Mangelsdorf DJ, Moore DD, Qin J, Steffen DL, Tsai MJ, Tsai SY, Yu R, Margolis RN, Evans RM, O'Malley BW: Minireview: Evolution of NURSA, the Nuclear Receptor Signaling Atlas. Mol Endocrinol 2009, 23(6):740-746

81. Havis E, Sachs LM, Demeneix BA: Metamorphic T3-response genes have specific co-regulator requirements. EMBO Reports 2003, 4:883-888.

82. Paul BD, Fu L, Buchholz DR, Shi Y-B: Coactivator recruitment is essential for liganded thyroid hormone receptor to initiate amphibian metamorphosis. Mol Cell Biol 2005, 25:5712-5724.

83. Paul BD, Buchholz DR, Fu L, Shi Y-B: Tissue- and gene-specific recruitment of steroid receptor coactivator-3 by thyroid hormone receptor during development. J Biol Chem 2005, 280:27165-27172

84. Paul BD, Buchholz DR, Fu L, Shi Y-B: SRC-p300 coactivator complex is required for thyroid hormone induced amphibian metamorphosis. $J$ Biol Chem 2007, 282:7472-7481.

85. Sachs LM, Shi Y-B: Targeted chromatin binding and histone acetylation in vivo by thyroid hormone receptor during amphibian development. PNAS 2000, 97:13138-13143.

86. Wang $X$, Matsuda $H$, Shi $Y$-B: Developmental regulation and function of thyroid hormone receptors and 9 -cis retinoic acid receptors during Xenopus tropicalis metamorphosis. Endocrinology 2008, 149:5610-5618

87. Sachs LM, Jones PL, Havis E, Rouse N, Demeneix BA, Shi Y-B: N-CoR recruitment by unliganded thyroid hormone receptor in gene repression during Xenopus laevis development. Mol Cell Biol 2002, 22:8527-8538.

88. Bilesimo P, Jolivet P, Alfama G, Buisine N, Le Mevel S, Havis E, Demeneix BA, Sachs LM: Specific Histone Lysine 4 Methylation Patterns Define TRBinding Capacity and Differentiate Direct T3 Responses. Mol Endocrinol 2011, 25:225-237. 
89. Matsuura K, Fujimoto K, Fu L, Shi Y-B: Liganded thyroid hormone receptor induces nucleosome removal and histone modifications to activate transcription during larval intestinal cell death and adult stem cell development. Endocrinology 2012, 153:961-972.

90. Sachs LM, Amano T, Shi YB: An essential role of histone deacetylases in postembryonic organ transformations in Xenopus laevis. Int $\mathrm{J}$ Mol Med 2001, 8(6):595-601.

91. Sachs LM, Amano T, Rouse N, Shi YB: Involvement of histone deacetylase at two distinct steps in gene regulation during intestinal development in Xenopus laevis. Dev Dyn 2001, 222(2):280-291.

92. Grimaldi A, Buisine N, Miller T, Shi YB, Sachs LM: Mechanisms of thyroid hormone receptor action during development: lessons from amphibian studies. Biochim Biophys Acta 2013, 1830(7):3882-3892.

93. Wong J, Shi Y-B: Coordinated regulation of and transcriptional activation by Xenopus thyroid hormone and retinoid X receptors. J Biol Chem 1995, 270:18479-18483.

94. Hsia VS-C, Shi Y-B: Chromatin Disruption and Histone Acetylation in the Regulation of HIV-LTR by Thyroid Hormone Receptor. Mol Cell Biol 2002, 22:4043-4052.

95. Guenther MG, Barak O, Lazar MA: The SMRT and N-CoR corepressors are activating cofactors for histone deacetylase 3. Mol Cell Biol 2001, 21(18):6091-6101.

96. Paul BD, Shi Y-B: Distinct expression profiles of transcriptional coactivators for thyroid hormone receptors during Xenopus laevis metamorphosis. Cell Research 2003, 13:459-464.

97. Fujimoto K, Matsuura K, Hu-Wang E, Lu R, Shi YB: Thyroid Hormone Activates Protein Arginine Methyltransferase 1 Expression by Directly Inducing c-Myc Transcription during Xenopus Intestinal Stem Cell Development. J Biol Chem 2012, 287(13):10039-10050.

98. Matsuura K, Fujimoto K, Das B, Fu L, Lu CD, Shi YB: Histone H3K79 methyltransferase Dot $1 \mathrm{~L}$ is directly activated by thyroid hormone receptor during Xenopus metamorphosis. Cell Biosci 2012, 2(1):25.

99. Sato Y, Buchholz DR, Paul BD, Shi Y-B: A role of unliganded thyroid hormone receptor in postembryonic development in Xenopus laevis. Mech Dev 2007, 124:476-488.

100. Nguyen AT, Zhang Y: The diverse functions of Dot1 and H3K79 methylation. Genes Dev 2011, 25(13):1345-1358.

101. Kouzarides T: Chromatin modifications and their function. Cell 2007. 128:693-705.

102. Cao R, Wang L, Wang H, Xia L, Erdjument-Bromage $H$, Tempst $P$, Jones RS, Zhang Y: Role of histone H3 lysine 27 methylation in Polycomb-group silencing. Science 2002, 298:1039-1043.

103. Cao R, Zhang Y: The functions of $E(Z) / E Z H 2-$ mediated methylation of lysine 27 in histone H3. Curr Opin Genet Dev 2004, 14:155-164.

104. Li B, Carey M, Workman JL: The role of chromatin during transcription. Cell 2007, 128:707-719.

105. Wang Z, Schones DE, Zhao K: Characterization of human epigenomes. Curr Opin Genet Dev 2009, 19(2):127-134.

106. Wang Z, Zang C, Rosenfeld JA, Schones DE, Barski A, Cuddapah S, Cui K, Roh TY, Peng W, Zhang MQ, Zhao K: Combinatorial patterns of histone acetylations and methylations in the human genome. Nat Genet 2008, 40(7):897-903.

107. Roh TY, Cuddapah S, Cui K, Zhao K: The genomic landscape of histone modifications in human T cells. Proc Natl Acad Sci U S A 2006, 103(43):15782-15787.

108. Barski A, Cuddapah S, Cui K, Roh TY, Schones DE, Wang Z, Wei G, Chepelev I, Zhao K: High-resolution profiling of histone methylations in the human genome. Cell 2007, 129(4):823-837.

109. Maunakea AK, Chepelev I, Zhao K: Epigenome mapping in normal and disease States. Circ Res 2010, 107:327-339.

110. Barth TK, Imhof A: Fast signals and slow marks: the dynamics of histone modifications. Trends Biochem Sci 2010, 35:618-626.

111. Shi YB: Unliganded thyroid hormone receptor regulates metamorphic timing via the recruitment of histone deacetylase complexes. Curr Top Dev Biol 2013, 105:275-297.

112. Huang J: Thematic series: Epigenetics in stem cells and cancer. Cell Biosci 2013, 3(1):38.

113. Tarayrah $L$, Chen $X$ : Epigenetic regulation in adult stem cells and cancers. Cell Biosci 2013, 3(1):41.
114. Gu B, Lee MG: Histone $\mathrm{H} 3$ lysine 4 methyltransferases and demethylases in self-renewal and differentiation of stem cells. Cell Biosci 2013, 3(1):39.

115. Kroll KL, Amaya E: Transgenic Xenopus embryos from sperm nuclear transplantations reveal FGF signaling requirements during gastrulation. Development 1996, 122(10):3173-3183.

116. Fu L, Buchholz D, Shi YB: Novel double promoter approach for identification of transgenic animals: A tool for in vivo analysis of gene function and development of gene-based therapies. Mol Reprod Dev 2002, 62(4):470-476.

117. Young JJ, Cherone JM, Doyon Y, Ankoudinova I, Faraji FM, Lee AH, Ngo C, Guschin DY, Paschon DE, Miller JC, Zhang L, Rebar EJ, Gregory PD, Urnov FD, Harland RM, Zeitler B: Efficient targeted gene disruption in the soma and germ line of the frog Xenopus tropicalis using engineered zincfinger nucleases. Proc Natl Acad Sci U S A 2011, 108(17):7052-7057.

118. Lei Y, Guo X, Liu Y, Cao Y, Deng Y, Chen X, Cheng CH, Dawid IB, Chen Y, Zhao $\mathrm{H}$ : Efficient targeted gene disruption in Xenopus embryos using engineered transcription activator-like effector nucleases (TALENs). Proc Natl Acad Sci U S A 2012, 109:17484-17489.

119. Lei Y, Guo X, Deng Y, Chen Y, Zhao H: Generation of gene disruptions by transcription activator-like effector nucleases (TALENs) in Xenopus tropicalis embryos. Cell Biosci 2013, 3(1):21.

120. Sun G, Shi Y-B: Thyroid hormone regulation of adult intestinal stem cell development: Mechanisms and evolutionary conservations. Int J Biol SCi 2012, 8:1217-1224

doi:10.1186/2045-3701-4-73

Cite this article as: Sun et al:: Epigenetic regulation of thyroid hormoneinduced adult intestinal stem cell development during anuran metamorphosis. Cell \& Bioscience 2014 4:73.

\section{Submit your next manuscript to BioMed Central and take full advantage of:}

- Convenient online submission

- Thorough peer review

- No space constraints or color figure charges

- Immediate publication on acceptance

- Inclusion in PubMed, CAS, Scopus and Google Scholar

- Research which is freely available for redistribution 